\title{
Pengaruh Konsentrasi dan Lama Perendaman Ekstrak Kulit Nanas Terhadap Kualitas Fidik dan Kualitas Organoleptik Daging Bebek Petelur Afkir
}

\section{The Influence of Concertation and Long Soaking the Skin Extract of Pineapple of Quality Physical and Quality Organoleptic of Unproductive of Duck Meat}

\author{
Musabihatul Maghfiroh ${ }^{1}$, Ratna Kumala Dewi, S.Pt, MMG, M.Eng ${ }^{2}$, Edy Susanto, SPt.,MP ${ }^{3}$ \\ ${ }^{1}$ Mahasiswa Fakultas Peternakan \\ ${ }^{2}$ Dosen Pembimbing Utama \\ ${ }^{3}$ Dosen Pembimbing Pendamping \\ Program Studi Peternakan \\ Fakultas Peternakan, Universitas Islam Lamongan (UNISLA)
}

\section{RINGKASAN}

Penelitian ini dilaksanakan pada tanggal 23 Mei sampai dengan 14 Juni 2016 dilakukan di Laboratorium Fakultas Peternakan Universitas Islam Lamongan. Penelitian ini bertujuan untuk mengetahui pengaruh konsentrasi dan lama perendaman ekstrak kulit nanas terhadap kualitas fisik dan organoleptik daging bebek petelur afkir. Materi Penelitian adalah daging bebek petelur afkir sebanyak 3 $\mathrm{kg}$ bagian dada dan paha tanpa tulang dan kulit nanas sebanyak $2 \mathrm{~kg}$. metode yang digunakan dalam penelitian ini adalah percobaan dengan Rancangan Acak Lengkap (RAL) pola faktorial (3x3) dengan 2 faktor dan 3 kali ulangan. Perlakuan yang diterapkan adalah fakor A terdiri dari $\mathrm{A}_{1}=$ konsentrasi ekstrak kulit nanas $0 \%$ (tanpa perendaman), $\mathrm{A}_{2}=$ konsentrasi ekstrak kulit nanas 20\% (20 ml ekstrak kulit nanas), $\mathrm{A}_{3}=$ konsentrasi ekstrak kulit nanas $40 \%$ (40 ml ekstrak kulit nanas), faktor $\mathrm{B}$ terdiri dari $\mathrm{B}_{1}=$ perendaman dengan waktu 0 menit, $\mathrm{B}_{2}=$ perendaman dengan waktu 30 menit, $\mathrm{B}_{3}=$ perendaman dengan waktu 60 menit. Data yang diperoleh dianalisis dengan sidik ragam Analysis Of Variace (ANOVA) dan dilanjutkan dengan Duncan's Multiple Range Test (DMRT) bila terdapat pengaruh nyata. Variabel yang diamati meliputi kualitas fisik (uji nilai pH dan susut masak) dan kualitas organoleptik (warna, aroma dan tekstur). Hasil penelitian menujukkan bahwa perendaman bebek afkir dalam ekstrak kulit nanas memberikan pengaruh tidak nyata $(\mathrm{P}>0.05)$ terhadap uji nilai $\mathrm{pH}$, susut masak, warna, aroma dan tekstur. Hasil penelitian ini menunjukkan bahwa pengaruh konsentrasi dan lama perendaman ekstrak kulit nanas terhadap kualitas fisik dan organoleptic daging bebek afkir tidak terjadi interaksi yang nyata $(\mathrm{P}<0,05)$ antara lama perendaman ekstrak kulit nanas dan konsentrasi yang berbeda terhadap pengempukan daging bebek petelur afkir, karena Fhitung $<$ Ftabel $(\mathrm{P}<0,05)$, tetapi berpengaruh nyata $(\mathrm{P}<0,05)$ terhadap $\mathrm{pH}$, warna dan tekstur, karena Fhitung $>$ Ftabel $(\mathrm{P}<0,05)$. Pada konsentrasi $20 \%$ selama 60 menit dapat meningkatkan presentasi tingkat kesukaan terhadap warna dengan nilai rata-rata $(31,88)$ dan tekstur dengan nilai rata-rata (30,77). Tetapi belum mampu memperbaiki nilai aroma, susut masak dan pengempukan ekstrak kulit nanas mampu menurunkan nilai $\mathrm{pH}$ daging bebek afkir dengan nilai rata-rata $(5,76)$.

\section{ABSTRACT}

This research was carried out on 23 May until 2 June 2016 done in laboratory animal husbandry Faculty of Islamic University of Lamongan. This research aims to know the influence of Concentration and long soaking the skin extract of pineapple to quality physical and organoleptic unproductive duck meat. The research material is unproductive duck meat as much as $3 \mathrm{~kg}$, the chest and thinghs without bone and skin the pineapple as much $2 \mathrm{~kg}$. the methods used in this study was a randomized Complete design experiments (RAL) factorial pattern $(3 \times 3)$ with two factors and repeat 3 times. The treatment applied was faktor $A$ consists of $A_{1}=$ pineapple skin exstract concentration of $0 \%$ (no submersion), $A_{2}=$ the concentration of the extract of pineapple sikn $20 \%$ ( $20 \mathrm{ml}$ pineapple skin extract), $\mathrm{A}_{3}=$ pineapple skin extract concentration of $40 \%$ ( $40 \mathrm{ml}$ pineapple skin extract), factor $\mathrm{B}$ consists of $\mathrm{B}_{1}=$ immersion with a time of 0 minutes, $B_{2}=$ soaking with a time of 30 minutes, $B_{3}=$ soaking with a time of 60 minutes. The obtained were analyzed with Analysis Of Variety Fingerprints Variace (ANOVA) and continued with the Duncan's Multiple Range Test (DMRT) when there is a real influence. The observed variables inclue 
physical quality ( $\mathrm{pH}$ value test and cooking loss) and organoleptick quality (Colour, odour, texture). The research shows that soaking duck in pineapple skin extract unproductive duck meat exert influence are not real $(\mathrm{P}>0,05)$ against the test value of $\mathrm{pH}$, shrinkage, color, odour, teksture. The results of this study indicate that the influence of concentration and long pineapple to quality physical and organoleptic meat duck afkir real interaction does not occur (p. $<0.05$ ) between long soaking the skin extract of pineapple and different concentration against the unproductive duck meat. Because Fhitung < Ftabel $(\mathrm{P}<0.05)$, but the real effect $(\mathrm{P}<0.05)$ against $\mathrm{pH}$, color and texture, because Fhitung $>$ Ftabel $(\mathrm{P}<0.05)$. At concentrations of $20 \%$ for 60 minutes can increase the level of fondness towards presentation of colors by the average value (31.88) and the texture with the average value $(30,77)$. But haven't been able to fix the value of scents, shrink Cook and pineapple skin extract were able to lower the $\mathrm{pH}$ value of the unproductive duck meat with average value $(5,76)$.

Keywods : Unproductive duck meat, pineapple skin, test the physical quality and test the quality of organoleptic.

\section{PENDAHULUAN}

Bebek adalah hewan yang telah didomestikasi (dipelihara) guna diambil daging, telur bahkan bulunya. Bebek yang telah didomestikasi ini berasal dari keturunan bebek liar. Indonesia merupakan negara penghasil daging terbesar ketiga di dunia (Ensminger et al., 1994) dalam (Yati, 2013). Bebek petelur afkir adalah bebek petelur digunakan sebagai bebek pedaging jika sudah tidak produktif lagi (afkir). Daging bebek petelur afkir umumnya kurang disukai karena dagingnya yang alot, liat (kenyal) dan keras dibandingkan dengan daging ayam. Produk bebek berupa daging dan telur, pemanfaatan daging bebek betina afkir ini diharapkan dapat membantu meningkatkan konsumsi daging masyarakat Indonesia yang masih rendah. Konsumen lebih menghendaki daging yang mempunyai mutu yang baik, terutama dalam hal keempukan, cita rasa, dan warna. Bebek afkir adalah bebek petelur yang telah melewati masa produksi. Salah satu produk yang belum mendapatkan perhatian khusus adalah pengolahan hasil ternak yaitu daging.

Lawrie (2003) menyatakan, tingkat keempukan daging dipengaruhi oleh protein jaringan pengikat dan semakin bertambahnya umur ternak akan meningkatkan jumlah jaringan ikat lebih banyak, sehingga meningkatkan kealotan daging. Tingkat keempukan daging dipengaruhi oleh struktur jaringan ikat pada daging dari hewan yang sudah tua, memiliki protein jaringan ikat atau jaringan ikatan silang yang semakin banyak jumlahnya, sehingga daging tersebut akan bersifat alot (keras). Sebaliknya daging dari hewan yang lebih muda memiliki jaringan ikat yang labil terhadap panas, sehingga ketika dimasak jaringan ikat tersebut mudah putus dan menghasilkan daging yang empuk. Agar daging bebek afkir disukai dan dikonsumsi oleh banyak orang, maka perlu diberi perlakuan atau teknologi untuk meningkatkan keempukannya dengan cara melunakkan daging tersebut.

Dalam rangka mengempukkan daging dan meningkatkan daya konsumsi daging bebek petelur afkir perlu adanya pengolahan daging sebelum dimasak yaitu dengan cara perendaman daging menggunakan kulit nanas. Kulit nanas mengandung enzim protease (proteolitik) yang disebut enzim bromelin. Enzim bromelin merupakan enzim protease yang dapat menghidrolisa protein sehingga dapat melunakkan daging. Sumber enzim bromelin yang secara alami terdapat pada buah nanas, batang nanas, ataupun kulit nanas. Nanas merupakan buah yang dapat diperoleh di seluruh Indonesia dan dapat dipanen sepanjang tahun. Enzim bromelin mudah di dapat karena buah nanas dapat berbuah sepanjang tahun dan tersebar di seluruh Indonesia. Umumnya limbah nanas yang berupa batang, daun, kulit dan bonggol belum dimanfaatkan lebih optimal. Sehingga penggunaan limbah kulit nanas sebagai bahan pengempuk daging belum dilakukan orang (Winastia, 2011).

\section{PROSEDUR ANALISIS Uji Nilai pH \\ $\mathrm{pH}$ (potential of hydrogen) adalah} derajat keasaman yang dipergunakan atau dipakai untuk menyatakan kebasaan (AsamBasa). Smith (1978) dalam (Dhiah, 2011). Pengujian $\mathrm{pH}$ sebagai berikut: 
1.Ujing $\mathrm{pH}$ dibilas dengan aquades dan dikeringkan.

2. Sampel daging seberat $10 \mathrm{~g}$ dicacah, ditambah $10 \mathrm{ml}$ aquades, diaduk hingga homogen.

3. Sampel diukur $\mathrm{pH}$ nya dengan $\mathrm{pH}$ meter yang telah dikalibrasi dengan buffer $\mathrm{pH} \quad 7,0$. Pengulangan dilakukan sebanyak 3 kali

4.Ujung $\mathrm{Ph}$ meter dicelupkan ke dalam sampel dan nilai $\mathrm{pH}$ terbaca dilayar, pengulangan dilakukan sebanyak 3 kali kemudian hasilnya dirata-rata.

\section{Uji Nilai Susut Masak (Cooking Loss)}

Susut masak adalah berat yang hilang selama pemasakan, makin tinggi suhu pemasakan dan makin lama waktu pemasakan, makin besar pula kadar cairan daging yang hilang sampai mencapai tingkat yang konstan. Susut masak merupakan indikator nilai nutrient daging yang berhubungan dengan kadar jus daging, yaitu banyaknya air yang terikat di dalam dan diantara serabut otot (Soeparno, 2005).

Sampel daging ditimbang dan dicatat bobot awal daging. Sampel daging direbus sampai mendidih. Lalu diangkat dan di didinginkan. Sampel ditimbang sampai beratnya konstan. Susut masak adalah nilai dari selisih berat sebelum dimasak dan sesudah dimasak dibagi berat sampel sebelum dimasak dikalikan 100 persen. Persentase susut masak dihitung dengan rumus sebagai berikut:

$$
\begin{aligned}
& \mathrm{SM}=\frac{x-y}{x} \times 100 \\
& \mathrm{x}=\text { Berat awal sebelum dimasak } \\
& \mathrm{y}=\text { Berat akhir sudah dimasak } \\
& \text { Sumber }: \text { Soeparno (1998) }
\end{aligned}
$$

\section{Uji Nilai Organoleptik}

Uji organoleptik dilakuakan setelah daging bebek petelur afkir direbus. Metode pengujian organoleptik dilakukan dengan uji mutu hedonic skala scoring. Metode ini merupakan metode untuk mengetahui sejauh mana tingkat skala penilaian yang disebut sakala hedoni. Uji organoleptik ini dilakukan secara subyektif (uji panelis) dengan mengguanakac oleh 10 orang panelis terlatih dari Mahasiswa semester delapan Fakultas Peternakan Universitas Islam Lamongan, dengan taraf 5 tingkat, yaitu taraf 1-5: taraf 1 (sanagat tidak suka), taraf 2 (tidak suka), taraf 3 (biasa), taraf 4 (suka), taraf 5 ( sangat suka). Data respon ditransformasi, hasil uji hedonik ke numerik dan data yang diperoleh dianalisa dengan Analisis Keragaman (Analysis of Variance), untuk mengetahui perlakuan-perlakuan mana yang berbeda nyata secara statistic dilakukan dengan pengujian berganda Duncan's Multiple Range Test (DMRT).

\section{METODE PENELITIAN}

Metode yang digunakan adalah metode eksperimen yaitu melakukan uji coba secara langsung di Laboratorium Fakultas Peternakan Universitas Islam Lamongan.

Penelitian ini dilakukan dengan menggunakan (RAL) Rancangan Acak Lengkap faktorial (3x3) terdiri dari 2 faktor perlakuan dan 3 kali ulangan. Masing-masing menggunakan 100 gram daging bebek petelur afkir.

1. Faktor Pertama : Konsentrasi (A)

$\mathrm{A}_{1}=$ Konsentrasi ekstrak kulit nanas 0\% (tanpa perlakuan)

$\mathrm{A}_{2}=$ Konsentrasi ekstrak kulit nanas 20\% (20 ml ekstrak kulit nanas)

$\mathrm{A}_{3}=$ Konsentrasi ekstrak kulit nanas 40\% (40 ml ekstrak kulit nanas)

2. Faktor Kedua : Waktu (B)

$\mathrm{B}_{1}=$ Perendaman dengan waktu 0 menit

$\mathrm{B}_{2}=$ Perendaman dengan waktu 30 menit

$\mathrm{B}_{3}=$ Perendaman dengan waktu 60 menit

\section{VARIABEL PENGAMATAN}

Variabel yang diamati dalam penelitian ini menurut Soekarto, 1985 adalah:

1. Kualitas fisik dan kimiawi : Parameter kualitas fisik yang diamati susut masak (cooking loss) dan nilai $\mathrm{pH}$.

2. Kualitas organoleptik : Parameter kualitas organoleptik yang diamati adalah warna, tekstur dan bau.

\section{ANALISIS DATA}

Menurut Steel, et al., 1995, analisis data yang digunakan adalah analisa varians (ANOVA) Jika terdapat perbedaan yang nyata antar perlakuan dilanjutkan dengan uji Duncan's Multiple Range Test (DMRT).

Yijk $\quad=\mu+\alpha \boldsymbol{i}+\beta \boldsymbol{j}+(\alpha \beta) \boldsymbol{i} \boldsymbol{j}+\boldsymbol{\varepsilon} \boldsymbol{i} \boldsymbol{j} \boldsymbol{k}$

Yijk: Nilai pengamatan untuk faktor A level kei, faktor B level ke-j, pada ulangan ke-k 
$\mu \quad$ : Rataan umum

$\alpha i \quad$ : Pengaruh faktor A pada level ke-i

$\beta j \quad$ : Pengaruh faktor B pada level ke-j

$(\alpha \beta) i j$ : Interaksi antara A dan B pada faktor A level ke-i, faktor B level ke-j

sijk: Galat percobaan untuk faktor A level ke-i, faktor B level ke-j, pada ulangan atau kelompok ke-k

\section{HASIL DAN PEMBAHASAN}

\section{Pengaruh Konsentrasi dan Lama Perendaman Ekstrak Kulit Nanas Terhadap Nilai pH Daging Bebek Petelur Afkir}

$\mathrm{pH}$ daging merupakan tingkat derajat keasaman dari daging, $\mathrm{pH}$ ditentukan karena pembentukan asam laktat pada daging yang merupakan hasil dari terjadinya proses glikogenolisis pada hewan, nilai $\mathrm{pH}$ daging berada pada kisaran 5,4 - 7,0. Kemudian terjadi peningkatan $\mathrm{pH}$ akibat pertumbuhan mikroorganisme (Forrest et al, 1975). Data pH daging bebek petelur afkir pada perendaman ekstrak kulit nanas dengan lama perendaman 0 , 30 dan 60 menit disajikan pada Tabel 4.1

Dapat dilihat bahwa perlakuan ekstrak kulit nanas dengan lama perendaman daging bebek petelur afkir tertinggi pada perendaman ekstrak kulit nanas yaitu $0 \%$ sebesar 6,33 dan terendah pada perlakuan sebesar 5,76 pada konsentrasi $40 \%$. Data $\mathrm{pH}$ daging bebek petelur afkir dengan penambahan ekstrak kulit nanas $0 \%, 20 \%$ dan $40 \%$ yang direndam selama 0,30 dan 60 menit disajikan pada Tabel 4.1 dibawah ini.

Tabel 4.1 Rata-rata Nilai pH Daging Bebek Petelur Afkir dengan Perendaman Ekstrak Kulit Nanas.

\begin{tabular}{|c|c|c|c|c|}
\hline \multirow{2}{*}{$\begin{array}{c}\text { FAKTOR A } \\
\text { (KONSENT } \\
\text { RASI) }\end{array}$} & \multicolumn{2}{|c|}{ FAKTOR B (WAKTU) } & \multirow{2}{*}{ RATA } \\
\cline { 2 - 4 } & $\begin{array}{c}\mathbf{0} \\
\text { menit }\end{array}$ & $\begin{array}{c}\mathbf{3 0} \\
\text { menit }\end{array}$ & $\begin{array}{c}\mathbf{6 0} \\
\text { menit }\end{array}$ & RATA \\
\hline $0 \%$ & 6,56 & 6,75 & 5,70 & $\mathbf{6 . 3 3}$ \\
\hline $20 \%$ & 6,04 & 6,14 & 6,15 & $\mathbf{6 . 1 1}$ \\
\hline $40 \%$ & 6,06 & 5,71 & 5,53 & $\mathbf{5 . 7 6}$ \\
\hline $\begin{array}{c}\text { RATA- } \\
\text { RATA }\end{array}$ & $\mathbf{6 . 2 2}$ & $\mathbf{6 . 2 0}$ & $\mathbf{5 . 7 9}$ & \\
\hline
\end{tabular}

Sumber : Data Primer diolah (2016)

Hasil perlakuan diatas memperlihatkan bahwa daging bebek petelur afkir menggunakan ekstrak kulit nanas dengan lama perendaman 30 menit dengan konsentrasi $(0 \%, 20 \%$ dan $40 \%)$ menit dan 60 menit dengan konsentrasi $(0 \%$, $20 \%$ dan $40 \%$ ) menurunkan $\mathrm{pH}$ daging dalam proses pengempukan daging bebek petelur afkir dibandingkan dengan lama perendaman 0 menit tanpa pemberian konsentrasi. Susut $\mathrm{pH}$ turun dikarenakan karena degradasi seluler tinggi, protein terlarut tinggi, karena susut masaknya tinggi. Hasil uji statistik analisis variansi (ANOVA) terdapat pada Tabel 4.2 dibawah ini.

Tabel 4.2. Hasil Analisis Variansi (ANOVA) Uji Nilai pH Daging Bebek Petelur Afkir dengan Konsentrasi dan Waktu Perendaman Ekstrak Kulit Nanas

\begin{tabular}{|c|c|c|c|c|c|c|}
\hline Sumber & \multirow{2}{*}{ JK } & \multirow{2}{*}{ Db } & \multirow{2}{*}{ KT } & \multirow{2}{*}{ Fhit } & \multicolumn{2}{|c|}{ F-Tabel } \\
\cline { 6 - 7 } & & & & & $\mathbf{5 \%}$ & $\mathbf{1 \%}$ \\
\hline P & 3,82 & 8 & 0,47 & $3,35^{*}$ & 2,51 & 37,71 \\
\hline A & 1,42 & 2 & 0,74 & $5,28^{*}$ & 3,55 & 6,01 \\
\hline B & 1,05 & 2 & 0,52 & $3,71 *$ & 3,55 & 6,01 \\
\hline A*B & 1,29 & 4 & 0,37 & 2,64 & 2,93 & 4,58 \\
\hline G & 2,52 & 18 & 0,14 & & & \\
\hline Total & 10,1 & 34 & & & & \\
\hline
\end{tabular}

Keterangan : (*) Berbeda Nyata $(\mathrm{P}>0,05)$

Sumber : Data Primer diolah (2016)

Secara umum, perlakuan perendaman pada ekstrak kulit nanas terhadap daging bebek afkir dengan konsentrasi dan waktu perendaman yang berbeda berpengaruh nyata terhadap $\mathrm{pH}$ daging bebek petelur afkir, karena $\mathrm{F}$ hitung $>\mathrm{F}$ tabel $5 \% \quad(\mathrm{P}<0,05)$. Faktor A (konsentrasi) berpengaruh nyata terhadap $\mathrm{pH}$ daging bebek afkir, karena $\mathrm{F}$ hitung $>\mathrm{F}$ tabel $5 \%(\mathrm{P}<0,05)$. Faktor B (waktu) berpengaruh nyata terhadap $\mathrm{pH}$ daging bebek petelur afkir, karena $\mathrm{F}$ hitung > $\mathrm{F}$ tabel 5\% $(\mathrm{P}<0,05)$. Sedangkan interaksi antara konsentrasi yang berbeda (A) dan Waktu perendaman yang berbeda (Faktor B) tidak berpengaruh terhadap $\mathrm{pH}$. karena $\mathrm{F}$ hitung $<\mathrm{F}$ tabel 5\% $(\mathrm{P}<0,05)$. Setelah diuji lanjut Duncan's hasil dari analisis menunjukkan $\mathrm{H}_{0}$ diterima (tidak berbeda nyata) karena Fhitung $<\mathrm{Rp}$ (rataan terpendek). Selisih rata-rata perlakuan. Dapat dilihat pada Tabel 4.3 di bawah ini.

Tabel 4.3 Matriks Selisih Rata-rata $\mathrm{pH}$ Daging Bebek Petelur Afkir dengan Konsentrasi dan Waktu perendaman Ekstrak Kulit Nanas. 


\begin{tabular}{|c|c|c|c|c|c|c|}
\hline $\mathbf{N}$ & Perlaku & Rata & $\begin{array}{l}40 \\
\%\end{array}$ & $\begin{array}{l}20 \\
\%\end{array}$ & $\begin{array}{l}\mathbf{0} \\
\%\end{array}$ & \multirow{2}{*}{$\begin{array}{c}\text { Nota } \\
\text { si }\end{array}$} \\
\hline $\mathbf{O}$ & & an & $\begin{array}{c}5,7 \\
7\end{array}$ & $\begin{array}{c}6,1 \\
1\end{array}$ & $\begin{array}{c}6,3 \\
4\end{array}$ & \\
\hline 1 & $40 \%$ & 5,77 & 0 & - & - & \multirow{3}{*}{$\mathrm{a}$} \\
\hline 2 & $20 \%$ & 6,11 & $\begin{array}{l}0,3 \\
4^{\text {a }}\end{array}$ & 0 & - & \\
\hline 3 & $0 \%$ & 6,34 & $\begin{array}{l}0,5 \\
7^{\mathrm{a}}\end{array}$ & $\begin{array}{l}0,2 \\
3^{\mathrm{a}} \\
\end{array}$ & 0 & \\
\hline
\end{tabular}

Keterangan : ( ${ }^{\mathrm{a}}$ ) Menunujukkan Tidak Berbeda Nyata

Sumber : Data Primer diolah (2016)

Menurut Buckle et al, (1987) pH tinggi 6.2 - 7.2 menyebabkan daging mempunyai struktur tertutup dan padat. Struktur tertutup pada daging menyebabkan penetrasi air ke dalam daging tidak sempurna, sehingga merubah keseimbangan hidrogen. Sehingga hasil penelitian ini secara statistic menujukkan bahwa penambahan konsentrasi ekstrak kulit nanas dengan konsentrasi 0\%, 20\% dan 40\% belum bisa memperbaiki nilai $\mathrm{pH}$.

\section{Pengaruh Konsentrasi dan Lama Perendaman Ekstrak Kulit Nanas Terhadap Nilai Susut Masak Daging Bebek Petelur Afkir}

Berdasarkan nilai data susut masak daging bebek petelur afkir pada perendaman ekstrak kulit nanas dengan lama perendaman 0 , 30 dan 60 menit dan konsentrasi 0\%, 20\% dan 40\% disajikan pada Tabel 4.4 dibawah ini.

Tabel 4.4 Rata-rata Nilai Susut Masak (\%) Daging Bebek Petelur Afkir dengan Pemberian Ekstrak Kulit Nanas.

\begin{tabular}{|c|c|c|c|c|}
\hline \multirow{2}{*}{$\begin{array}{c}\text { FAKTOR A } \\
\text { (KONSENT } \\
\text { RASI) }\end{array}$} & \multicolumn{3}{|c|}{ FAKTOR B (WAKTU) } & \multirow[b]{2}{*}{$\begin{array}{l}\text { RATA- } \\
\text { RATA }\end{array}$} \\
\hline & $\begin{array}{c}0 \\
\text { menit }\end{array}$ & $\begin{array}{c}30 \\
\text { menit }\end{array}$ & $\begin{array}{c}60 \\
\text { menit }\end{array}$ & \\
\hline $0 \%$ & 34,26 & 36,59 & 31,90 & 34,23 \\
\hline $20 \%$ & 38,15 & 38,98 & 38,04 & 38,39 \\
\hline $40 \%$ & 37,30 & 35,73 & 40,77 & 37,93 \\
\hline $\begin{array}{l}\text { RATA- } \\
\text { RATA }\end{array}$ & 36,57 & $\mathbf{3 7 , 1 0}$ & 36,90 & \\
\hline
\end{tabular}

Sumber : Data Primer diolah (2016)

Nilai rata-rata terendah susut masak $(34,23)$ pada konsentrasi $0 \%$, kemudian diikuti oleh perlakuan konsentrasi $40 \%(37,93)$, dan tertinggi pada konsentrasi $20 \%(38,39)$. Untuk mengetahui adanya pengaruh perendaman dengan konsentrasi $(0 \%, 20 \%$ dan 40\%) dengan wkatu (0 menit, 30 menit dan 60 menit) terhadap nilai susut masak daging bebek petelur afkir dilakukan uji sidik ragam yang terdapat pada Lampiran 6. Hasil uji statistic analisis variansi (ANOVA) terdapat pada Tabel 4.5 dibawah ini.

Tabel 4.5 Hasil Analisis Variansi (ANOVA) Uji Nilai Susut Masak (\%) Daging Bebek Afkir dengan Perendaman Ekstrak Kulit Nanas

\begin{tabular}{|c|c|c|c|c|c|c|}
\hline \multirow{2}{*}{$\begin{array}{c}\text { Sumber } \\
\text { Keragaman }\end{array}$} & \multirow{2}{*}{ JK } & \multirow{2}{*}{ Db } & \multirow{2}{*}{ KT } & \multirow{2}{*}{ Fhit } & \multicolumn{2}{|c|}{ F-Tabel } \\
\hline P & 167,47 & 8 & 20,93 & 2,49 & 2,51 & 37,71 \\
\hline A & 92,88 & 2 & 46,44 & $\begin{array}{c}5,54 \\
*\end{array}$ & 3,55 & 6,01 \\
\hline B & 1,30 & 2 & 0,65 & 0,07 & 3,55 & 6,01 \\
\hline A*B & 73,29 & 4 & 18,32 & 2,18 & 2,93 & 4,58 \\
\hline G & 150,81 & 18 & 8,37 & & & \\
\hline Total & 485.75 & 34 & & & & \\
\hline
\end{tabular}

Keterangan : (*) Berbeda Nyata $(\mathrm{P}>0,05)$

Sumber : Data Primer diolah (2016)

Secara umum, perlakuan perendaman pada ekstrak kulit nanas terhadap daging bebek afkir dengan konsentrasi dan waktu perendaman yang berbeda berpengaruh tidak nyata terhadap susut masak daging bebek afkir, karena $\mathrm{F}$ hitung $<\mathrm{F}$ tabel $5 \%(\mathrm{P}<0,05)$. Faktor A (konsentrasi) berpengaruh nyata terhadap susut masak daging bebek afkir karena $\mathrm{F}$ hitung $>\mathrm{F}$ tabel 5\% $(\mathrm{P}<0,05)$. Faktor B (waktu) tidak berpengaruh nyata terhadap susut masak daging bebek afkir, karena $\mathrm{F}$ hitung $<\mathrm{F}$ tabel 5\% $\quad(\mathrm{P}<0,05)$. Sedangkan interaksi antara konsentrasi yang berbeda (A) dan Waktu perendaman yan berbeda (Faktor B) tidak berpengaruh terhadap susut masak, karena $\mathrm{F}$ hitung < $\mathrm{F}$ tabel 5\% $(\mathrm{P}<0,05)$. Setelah diuji lanjut Duncan's hasil dari analisis menunjukkan $\mathrm{H}_{0}$ diterima (tidak berbeda nyata) karena Fhitung < Rp (rataan terpendek). Selisih rata-rata perlakuan.

Tabel 4.6 Matriks Selisih Rata-rata Susut Masak (\%) Daging Bebek Petelur Afkir dengan Konsentrasi dan Waktu perendaman Ekstrak Kulit Nanas. 


\begin{tabular}{|c|c|c|c|c|c|c|}
\hline \multirow{2}{*}{$\begin{array}{l}\mathbf{N} \\
\mathbf{0}\end{array}$} & \multirow{2}{*}{$\begin{array}{c}\text { Perlak } \\
\text { uan }\end{array}$} & \multirow{2}{*}{$\begin{array}{l}\text { Rata } \\
\text { an }\end{array}$} & $\begin{array}{l}40 \\
\%\end{array}$ & $\begin{array}{l}20 \\
\%\end{array}$ & $\begin{array}{l}0 \\
\%\end{array}$ & \multirow{2}{*}{$\begin{array}{c}\text { Not } \\
\text { asi }\end{array}$} \\
\hline & & & $\begin{array}{l}34, \\
24\end{array}$ & $\begin{array}{l}\text { 37, } \\
93\end{array}$ & $\begin{array}{l}38, \\
39\end{array}$ & \\
\hline 1 & $40 \%$ & 34,24 & 0 & - & - & \multirow{3}{*}{ A } \\
\hline 2 & $20 \%$ & 37,93 & $\begin{array}{l}3,6 \\
9^{\text {a }}\end{array}$ & 0 & - & \\
\hline 3 & $0 \%$ & 38,39 & $\begin{array}{l}4,1 \\
5^{\mathrm{a}} \\
\end{array}$ & $\begin{array}{l}0,4 \\
6^{\text {a }} \\
\end{array}$ & 0 & \\
\hline
\end{tabular}

Keterangan : $\left({ }^{\mathrm{a}}\right)$ Menunjukkan Tidak berbeda Nyata

Sumber : Data Primer diolah (2016)

Hasil uji lanjut Duncan's Multiple Range Test (DMRT) menunjukkan bahwa perendaman ekstrak kulit nanas pada daging bebek afkir dengan konsentrasi $0 \%$ sampai dengan $40 \%$ menunjukkan pengaruh tidak nyata $(\mathrm{P}<0,05)$. Hal ini dikarenakan enzim proteolitik pada ekstrak kulit nanas belum mampu bekerja sehingga tidak terjadi pengaruh. Enzim protease yang tidak mampu masuk kedalam daging dan menambah jumlah protein terlarut akan menyebabkan tidak terjadinya perubahan yang nyata terhadap susut masak. Menurut Shanks et al, (2002), besarnya susut masak dipengaruhi oleh banyaknya kerusakan membran seluler, banyaknya air yang keluar dari daging, degradasi protein dan kemampuan daging untuk mengikat air. Menurut Obuz et al, (2004), meningkatnya susut masak ada hubungannya dengan serat otot dan penyusutan kolagen. Peningakatan susut masak juga dipengaruhi oleh laju penurunan $\mathrm{pH}$ daging.

Besarnya susut masak dapat dipergunakan untuk mengestimasikan jumlah kandungan air dan lemak dalam daging setelah dimasak. Daging dengan susut masak yang lebih rendah mempunyai kualitas relatif lebih baik daripada daging dengan susut masak yang lebih besar, karena kehilangan nutrisi selama pemasakan akan lebih sedikit (Soeparno, 1992). Persentase susut masak daging bebek petelur afkir pada kontrol atau tanpa perlakuan lebih kecil dibandingkan susut masak yang diberi perlakuan, hal ini berhubungan dengan rata-rata $\mathrm{pH}$ kontrol yang lebih besar jika dibandingkan dengan rata-rata $\mathrm{pH}$ yang diberi perlakuan. Sesuai dengan pendapat Forrest et al (1975) bahwa, dalam $\mathrm{pH}$ akhir yang rendah karena banyaknya asam laktat, maka gugus reaktif protein berkurang dan menyebabkan banyak air yang keluar, sehingga susut masak meningkat.

Meningkatnya nilai susut masak dapat disebabkan karena perendaman dengan enzim bromelin dapat mempercepat penurunan $\mathrm{pH}$ daging yang berakibat lebih cepat dilepaskannya enzim protease. Enzim ini akan mengakibatkan pecahnya fibrilar-fibrilar otot sehingga menurunnya kemampuan daging untuk mengikat air dan akan menyebabkan peningkatan nilai presentase susut masak daging (Soeparno 2009). Menurut Lawrie (2003) nilai susut masak daging yang normal adalah 1,5 \% sampai 54,5 \% dengan kisaran $15 \%-40 \%$. Sifat mekanik daging termasuk susut masak merupakan indikasi dari sifat mekanik miofibril dan jaringan ikat dengan bertambahnya umur ternak, terutama peningkatan panjang Sarkomer.

\section{KUALITAS ORGANOLEPTIK}

\section{Warna}

Berdasarkan nilai data warna daging bebek petelur afkir pada perendaman ekstrak kulit nanas dengan lama perendaman 0, 30 dan 60 menit dan konsentrasi $0 \%, 20 \%$ dan $40 \%$. Rerata nilai warna daging bebek afkir dengan penambahan ekstrak kulit nanas pada konsentrasi $0 \%, 20 \%$ dan $40 \%$ masing-masing adalah $31,43 \%, 29,21 \%$ dan $28,10 \%$.

Tabel 4.7 Rata-rata Nilai Warna Daging Bebek Petelur Afkir dengan Pemberian Ekstrak Kulit Nanas.

\begin{tabular}{|c|c|c|c|c|}
\hline $\begin{array}{c}\text { FAKTOR A } \\
\text { (KONSENTRA }\end{array}$ & \multicolumn{3}{|c|}{ FAKTOR B (WAKTU) } & \multirow{2}{*}{ RATA- } \\
\cline { 2 - 4 } SI) & $\begin{array}{c}\mathbf{0} \\
\text { menit }\end{array}$ & $\begin{array}{c}\mathbf{3 0} \\
\text { menit }\end{array}$ & $\begin{array}{c}\mathbf{6 0} \\
\text { menit }\end{array}$ & \\
\hline $0 \%$ & 30,3 & 30,3 & 29,33 & $\mathbf{2 9 , 9 7}$ \\
\hline $20 \%$ & 32 & 31 & 32,66 & $\mathbf{3 1 , 8 8}$ \\
\hline $40 \%$ & 32 & 26,33 & 22,33 & $\mathbf{2 6 , 8 8}$ \\
\hline RATA-RATA & $\mathbf{3 1 , 4 4}$ & $\mathbf{2 9 , 2 1}$ & $\mathbf{2 8 , 1 0}$ & \\
\hline
\end{tabular}

Nilai rata-rata warna terendah $(26,88)$

pada perlakuan $40 \%$, kemudian diikuti oleh perlakuan konsentrasi $0 \%(29,97)$, dan tertinggi pada konsentrasi $20 \% \quad(31,88)$. Untuk mengetahui adanya pengaruh perendaman dengan konsentrasi $(0 \%, 20 \%$ dan $40 \%)$ dengan waktu (0 menit, 30 menit dan 60 menit) terhadap warna daging bebek petelur afkir dilakukan uji sidik ragam yang terdapat pada Lampiran 7. Hasil uji statistik analisis variansi (ANOVA) terdapat pada Tabel 4.8 dibawah ini. 
Tabel 4.8 Hasil Analisis Variansi (ANOVA) Uji Nilai Warna Daging Bebek Petelur Afkir dengan Perendaman Ekstrak Kulit Nanas

\begin{tabular}{|c|c|c|c|c|c|c|}
\hline \multirow{2}{*}{$\begin{array}{c}\text { Sumber } \\
\text { Keragam } \\
\text { an }\end{array}$} & JK & Db & KT & Fhit & $\mathbf{5 \%}$ & $\mathbf{1 \%}$ \\
\hline P & 262,51 & 8 & 32,81 & $3,43^{*}$ & 2,51 & 37,71 \\
\hline A & 114,74 & 2 & 57,37 & $6,00^{*}$ & 3,55 & 6,01 \\
\hline B & 51,85 & 2 & 25,92 & 2,71 & 3,55 & 6,01 \\
\hline A*B & 95,92 & 4 & 23,98 & 2,50 & 2,93 & 4,58 \\
\hline G & 172 & 18 & 9,55 & & & \\
\hline Total & 700,02 & 34 & & & & \\
\hline
\end{tabular}

Keterangan : (*) Berpengaruh Nyata $(\mathrm{P}>0,05)$

Sumber : Data Primer diolah (2016)

Secara umum, perlakuan perendaman pada ekstrak kulit nanas terhadap daging bebek afkir dengan konsentrasi dan waktu perendaman yang berbeda berpengaruh nyata terhadap warna daging bebek petelur afkir, karena $\mathrm{F}$ hitung $>\mathrm{F}$ tabel $5 \% \quad(\mathrm{P}<0,05)$. Faktor A (konsentrasi) berpengaruh nyata terhadap warna daging bebek afkir karena $\mathrm{F}$ hitung $>\mathrm{F}$ tabel 5\% $(\mathrm{P}<0,05)$. Faktor B (waktu) tidak berpengaruh nyata terhadap warna daging bebek petelur afkir, karena $\mathrm{F}$ hitung $<\mathrm{F}$ tabel $5 \% \quad(\mathrm{P}<0,05)$. Sedangkan interaksi antara konsentrasi yang berbeda (A) dan waktu perendaman yang berbeda (Faktor B) tidak berpengaruh terhadap warna, karena $\mathrm{F}$ hitung $<\mathrm{F}$ tabel $5 \%(\mathrm{P}<0,05)$. Setelah diuji lanjut Duncan's hasil dari analisis menunjukkan $\mathrm{H}_{0}$ diterima (tidak berbeda nyata) karena Fhitung $<$ Rp (rataan terpendek). Selisih rata-rata perlakuan.

Tabel 4.9 Matriks Selisih Rata-rata Warna Daging Bebek Petelur Afkir dengan Konsentrasi dan Waktu perendaman Ekstrak Kulit Nanas.

\begin{tabular}{|c|c|c|c|c|c|c|}
\hline N & Perla & Rata & $\mathbf{4 0}$ \% & $\mathbf{2 0} \%$ & $\mathbf{0} \%$ & No \\
\cline { 4 - 6 } O & kuan & an & $\mathbf{2 6 , 8 9}$ & $\mathbf{3 0}$ & $\mathbf{3 1 , 8 9}$ & tasi \\
\hline 1 & $40 \%$ & 26,89 & 0 & - & - & \multirow{2}{*}{ A } \\
\hline 2 & $20 \%$ & 30 & $3,11^{\text {a }}$ & 0 & - & \multirow{2}{*}{ A } \\
\hline 3 & $0 \%$ & 31,89 & $5^{\text {a }}$ & $1,89^{\text {a }}$ & 0 & \\
\hline
\end{tabular}

Keterangan : $\left({ }^{a}\right)$ Menunjukkan Tidak Berbeda Nyata

Sumber : Data Primer diolah (2016)
Hasil uji lanjut Duncan's Multiple Range Test (DMRT) menunjukkan bahwa penambahan ekstrak kulit nanas konsentrasi $0 \%$ sampai konsentrasi $40 \%$ menunjukkan pengaruh tidak nyata $(\mathrm{P}<0.05)$ terhadap warna daging bebek afkir. Hal ini disebabkan karena penambahan ekstrak kulit nanas belum mempengaruhi mioglobin. Kandungan mioglobin daging merupakan faktor utama yang mempengaruhi warna daging, semakin banyak kandungan mioglobin daging maka warna daging akan semakin merah.

Menurut Arbele et al, (2001) menyatakan warna daging sangat dipengaruhi dengan jumlah kandungan mioglobinnya. Menurut Forrest et al, (1975) warna daging dipengaruhi oleh pigmen daging, pigmen daging tersusun atas dua macam protein, yaitu hemoglobin dan mioglobin. Kadar mioglobin bervariasi jumlahnya tergantung spesies, umur, seks dan aktivitas fisik hewan.

Hasil yang menunjukkan pengaruh yang tidak nyata pada perlakuan konsentrasi terhadap warna daging juga disebabkan oleh nilai $\mathrm{pH}$ yang menunjukkan pengaruh tidak nyata. Warna daging dipengaruhi oleh $\mathrm{pH}$. Penambahan ekstrak kulit nanas selama proses perendaman daging konsentrasi 0\% sampai konsentrasi $40 \%$ belum mampu menaikkan nilai $\mathrm{pH}$, karena enzim proteolitik dari ekstrak kulit nanas belum mampu bekerja menghidrolisis asam laktat yang dihasilkan oleh glikosisis daging sehingga tidak mempengaruhi nilai $\mathrm{pH}$ sehingga tidak terjadi perubahan warna pada daging bebek petelur afkir. Faktor-faktor yang mempengaruhi warna daging adalah $\mathrm{pH}$ (Soeparno, 2005).

\section{Aroma}

Berdasarkan nilai data aroma daging bebek petelur afkir pada perendaman ekstrak kulit nanas dengan lama perendaman 0, 30 dan 60 menit dan konsentrasi 0\%, 20\% dan 40\%.

Tabel 4.10. Rata-rata Nilai Aroma Daging Bebek Petelur Afkir Dengan Pemberian Ekstrak Kulit Nanas. 


\begin{tabular}{|c|c|c|c|c|}
\hline \multirow{2}{*}{$\begin{array}{c}\text { FAKTOR A } \\
\text { (KONSENT } \\
\text { RASI) }\end{array}$} & \multicolumn{3}{|c|}{ FAKTOR B (WAKTU) } & \multirow{2}{*}{$\begin{array}{l}\text { RATA- } \\
\text { RATA }\end{array}$} \\
\hline & $\begin{array}{c}0 \\
\text { menit }\end{array}$ & $\begin{array}{c}30 \\
\text { menit }\end{array}$ & $\begin{array}{c}60 \\
\text { menit }\end{array}$ & \\
\hline $0 \%$ & 26,33 & 25,33 & 26,33 & 25,99 \\
\hline $20 \%$ & 26,33 & 32,33 & 30,33 & 29,66 \\
\hline $40 \%$ & 29,67 & 28,33 & 27,67 & 28,55 \\
\hline $\begin{array}{l}\text { RATA- } \\
\text { RATA }\end{array}$ & 27,44 & 28,66 & 28,11 & \\
\hline
\end{tabular}

Sumber : Data Primer diolah (2016)

Nilai rata-rata aroma terendah $(25,99)$ pada perlakuan $0 \%$, kemudian diikuti oleh perlakuan konsentrasi $40 \%(28,55)$, dan tertinggi pada konsentrasi $20 \% \quad(29,66)$. Untuk mengetahui adanya pengaruh perendaman dengan konsentrasi $(0 \%, 20 \%$ dan $40 \%)$ dengan waktu (0 menit, 30 menit dan 60 menit) terhadap warna daging bebek petelur afkir dilakukan uji sidik ragam yang terdapat pada lampiran 8 . Hasil uji statistik analisis variansi (ANOVA) terdapat pada Tabel 4.11

Tabel 4.11 Hasil Analisis Variansi (ANOVA) Uji Nilai Aroma Daging Bebek Petelur Afkir dengan Perendaman Ekstrak Kulit Nanas

\begin{tabular}{|c|c|c|c|c|c|c|}
\hline \multirow{2}{*}{ SK } & \multirow{2}{*}{ JK } & $\mathbf{D}$ & \multirow{2}{*}{ KT } & \multirow{2}{*}{ Fhit } & \multicolumn{2}{|c|}{ F-Tabel } \\
\cline { 5 - 7 } & & $\mathbf{b}$ & & & $\mathbf{5 \%}$ & $\mathbf{1 \%}$ \\
\hline P & 127,8 & 8 & 15,98 & $2,61 *$ & 2,51 & 37,71 \\
\hline A & 63,6 & 2 & 31,81 & $5,20 *$ & 3,55 & 6,01 \\
\hline B & 6,7 & 2 & 3,37 & 0,55 & 3,55 & 6,01 \\
\hline A*B & 57,4 & 4 & 14,37 & 2,35 & 2,93 & 4,58 \\
\hline G & 110 & 18 & 6,11 & & & \\
\hline Total & 365.7 & 34 & & & & \\
\hline
\end{tabular}

Keterangan : (*) Berbeda Nyata $(\mathrm{P}>0,05)$

Sumber : Data Primer diolah (2016)

Secara umum, perlakuan perendaman pada ekstrak kulit nanas terhadap daging bebek petelur afkir dengan konsentrasi dan waktu perendaman yang berbeda berpengaruh nyata terhadap aroma daging bebek afkir, karena $\mathrm{F}$ hitung > F tabel $5 \%(\mathrm{P}<0,05)$. Faktor A (konsentrasi) berpengaruh nyata terhadap aroma daging bebek afkir karena $\mathrm{F}$ hitung $>\mathrm{F}$ tabel 5\% $(\mathrm{P}<0,05)$. Faktor $\mathrm{B}$ (waktu) tidak berpengaruh nyata terhadap aroma daging bebek petelur afkir, karena $\mathrm{F}$ hitung $<\mathrm{F}$ tabel 5\% $\quad(\mathrm{P}<0,05)$.
Sedangkan interaksi antara konsentrasi yang berbeda (A) dan waktu perendaman yang berbeda (Faktor B) tidak berpengaruh terhadap aroma, karena $\mathrm{F}$ hitung < $\mathrm{F}$ tabel $5 \%(\mathrm{P}<0,05)$. Setelah diuji lanjut Duncan's hasil dari analisis menunjukkan $\mathrm{H}_{0}$ diterima (tidak berbeda nyata) karena Fhitung $<$ Rp (rataan terpendek). Selisih rata-rata perlakuan.

Tabel 4.12. Matriks Selisih Rata-rata Aroma Daging Bebek Petelur Afkir dengan Konsentrasi dan Waktu perendaman Ekstrak Kulit Nanas.

\begin{tabular}{|c|c|c|c|c|c|c|}
\hline \multirow{2}{*}{$\begin{array}{l}\mathbf{N} \\
\mathbf{O}\end{array}$} & \multirow{2}{*}{$\begin{array}{c}\text { Perlak } \\
\text { uan }\end{array}$} & \multirow{2}{*}{$\begin{array}{l}\text { Rata } \\
\text { an }\end{array}$} & $\begin{array}{l}40 \\
\%\end{array}$ & $\begin{array}{l}20 \\
\%\end{array}$ & $\begin{array}{l}0 \\
\%\end{array}$ & \multirow{2}{*}{$\begin{array}{c}\text { Not } \\
\text { asi }\end{array}$} \\
\hline & & & 26 & $\begin{array}{l}28, \\
56\end{array}$ & $\begin{array}{l}29, \\
67\end{array}$ & \\
\hline 1 & $40 \%$ & 26 & 0 & - & - & \multirow{3}{*}{ A } \\
\hline 2 & $20 \%$ & 28,56 & $\begin{array}{r}2,5 \\
6^{a}\end{array}$ & 0 & - & \\
\hline 3 & $0 \%$ & 29,67 & $\begin{array}{l}3,6 \\
7^{\text {a }}\end{array}$ & $\begin{array}{l}1,1 \\
1^{\mathrm{a}}\end{array}$ & 0 & \\
\hline
\end{tabular}

Keterangan : $\left({ }^{\mathrm{a}}{ }\right)$ Menunjukkan Tidak Berbeda Nyata

Sumber : Data Primer diolah (2016)

Hasil uji lanjut Duncan's Multiple Range Test (DMRT) menunjukkan bahwa perendaman ekstrak kulit nanas $0 \%$ sampai konsentrasi $40 \%$ menunjukan pengaruh yang tidak nyata $(\mathrm{P}<0,05)$ terhadap aroma daging bebek afkir. Hal ini dikarenakan daging bebek petelur afkir mempunyai ciri khas aroma yang amis, sehingga penambahan ekstrak kulit nanas $0 \%$ sampai dengan konsentrasi $40 \%$ belum mampu mempengaruhi aroma daging. Hal ini sesuai dengan pendapat Zuhra (2006) menyatakan bahwa indera pencium yaitu hidung memiliki kemampuan yang terbatas, evaluasi bau masih tergantung pada testing panel atau secara sensori.

\section{Tekstur}

Rata-rata nilai tekstur pada daging bebek afkir terhadap konsentrasi ekstrak kulit nanas $(0 \%, 20 \%$ dan $40 \%)$ selama perendaman (0 menit, 30 menit dan 60 menit). Disajikan pada Tabel 4.13 dibawah ini.

Tabel 4.13 Rata-rata Nilai Tekstur Daging Bebek Petelur Afkir dengan Pemberian Ekstrak Kulit Nanas. 


\begin{tabular}{|c|c|c|c|c|}
\hline \multirow{2}{*}{$\begin{array}{c}\text { FAKTOR } \\
\text { A } \\
\text { (KONSEN } \\
\text { TRASI) }\end{array}$} & \multicolumn{3}{|c|}{ FAKTOR B (WAKTU) } & \multirow{2}{*}{$\begin{array}{c}\text { RATA } \\
- \\
\text { RATA }\end{array}$} \\
\hline & $\begin{array}{c}0 \\
\text { menit }\end{array}$ & $\begin{array}{c}30 \\
\text { menit }\end{array}$ & $\begin{array}{c}60 \\
\text { menit }\end{array}$ & \\
\hline $0 \%$ & 27,33 & 26 & 27 & 26,77 \\
\hline $20 \%$ & 30 & 30 & 32,33 & 30,77 \\
\hline $40 \%$ & 31 & 30,33 & 29 & 30,11 \\
\hline $\begin{array}{l}\text { RATA- } \\
\text { RATA }\end{array}$ & 29,44 & 28,77 & 29,44 & \\
\hline
\end{tabular}

Sumber : Data Primer diolah (2016)

Nilai rata-rata tekstur terendah $(26,77)$ pada perlakuan $0 \%$, kemudian diikuti oleh perlakuan konsentrasi $40 \%(30,11)$, dan tertinggi pada konsentrasi $20 \% \quad(30,77)$. Untuk mengetahui adanya pengaruh perendaman dengan konsentrasi $(0 \%, 20 \%$ dan $40 \%)$ dengan waktu (0 menit, 30 menit dan 60 menit) terhadap warna daging bebek petelur afkir dilakukan uji sidik ragam yang terdapat pada lampiran 9. Hasil uji statistik analisis variansi (ANOVA) terdapat pada Tabel 4.14 dibawah ini.

Tabel 4.14 Hasil Analisis Variansi (ANOVA) Uji Nilai Tekstur Daging Bebek Afkir dengan Perendaman Ekstrak Kulit Nanas

\begin{tabular}{|c|c|c|c|c|c|c|}
\hline \multirow{2}{*}{ SK } & \multirow{2}{*}{ JK } & db & \multirow{2}{*}{ KT } & \multirow{2}{*}{ Fhit } & \multicolumn{2}{|c|}{ F-Tabel } \\
\hline P & 102,66 & 8 & 12,83 & 1,80 & 2,51 & $\begin{array}{c}37,7 \\
1\end{array}$ \\
\hline A & 82,66 & 2 & 41,33 & $\begin{array}{c}5,81 \\
*\end{array}$ & 3,55 & 6,01 \\
\hline B & 2,66 & 2 & 1,33 & 0,18 & 3,55 & 6,01 \\
\hline A*B & 17,33 & 4 & 4,33 & 0,60 & 2,93 & 4,58 \\
\hline G & 128 & 18 & 7,11 & & & \\
\hline Total & 333,31 & 34 & & & & \\
\hline
\end{tabular}

Keterangan : (*) Berbeda Nyata $(\mathrm{P}>0,05)$

Sumber : Data Primer diolah (2016)

Secara umum, perlakuan perendaman pada ekstrak kulit nanas terhadap daging bebek afkir dengan konsentrasi dan waktu perendaman yang berbeda berpengaruh tidak nyata terhadap tekstur daging bebek afkir, karena $\mathrm{F}$ hitung $<\mathrm{F}$ tabel $5 \% \quad(\mathrm{P}<0,05)$. Faktor A (konsentrasi) berpengaruh nyata terhadap tekstur daging bebek afkir karena $\mathrm{F}$ hitung > F tabel 5\% $(\mathrm{P}<0,05)$. Faktor B (waktu) tidak berpengaruh nyata terhadap tekstur daging bebek petelur afkir, karena $\mathrm{F}$ hitung < $\mathrm{F}$ tabel $5 \%(\mathrm{P}<0,05)$. Sedangkan interaksi antara konsentrasi yang berbeda (A) dan waktu perendaman yang berbeda (Faktor B) tidak berpengaruh terhadap tekstur, karena $\mathrm{F}$ hitung < F tabel 5\% $(\mathrm{P}<0,05)$. Setelah diuji lanjut Duncan's hasil dari analisis menunjukkan $\mathrm{H}_{0}$ diterima (tidak berbeda nyata) karena Fhitung $<$ Rp (rataan terpendek). Selisih rata-rata perlakuan.

Tabel 4.15. Matriks Selisih Rata-rata Tekstur Daging Bebek Petelur Afkir dengan Konsentrasi dan Waktu perendaman Ekstrak Kulit Nanas.

\begin{tabular}{|c|c|c|c|c|c|c|}
\hline \multirow{2}{*}{$\begin{array}{l}\mathbf{N} \\
\mathbf{O}\end{array}$} & \multirow{2}{*}{$\begin{array}{c}\text { Perlak } \\
\text { uan }\end{array}$} & \multirow{2}{*}{$\begin{array}{c}\text { Rataa } \\
\mathbf{n}\end{array}$} & $\begin{array}{l}40 \\
\%\end{array}$ & $\begin{array}{l}20 \\
\%\end{array}$ & $\begin{array}{l}\mathbf{0} \\
\%\end{array}$ & \multirow{2}{*}{$\begin{array}{c}\text { Nota } \\
\text { si }\end{array}$} \\
\hline & & & $\begin{array}{c}5,7 \\
7\end{array}$ & $\begin{array}{c}6,1 \\
1\end{array}$ & $\begin{array}{c}6,3 \\
4\end{array}$ & \\
\hline 1 & $40 \%$ & 26,78 & 0 & - & - & \multirow{3}{*}{ A } \\
\hline 2 & $20 \%$ & 30,11 & $\begin{array}{l}3,3 \\
3^{a}\end{array}$ & 0 & - & \\
\hline 3 & $0 \%$ & 30,77 & $\begin{array}{l}3,9 \\
9^{a}\end{array}$ & $\begin{array}{l}0,6 \\
6^{a}\end{array}$ & 0 & \\
\hline
\end{tabular}

Keterangan : $\left({ }^{\mathrm{a}}\right)$ Menunjukkan Tidak Berbeda Nyata

Sumber : Data Primer diolah (2016)

Hasil uji lanjut Duncan's Multiple Range Test (DMRT) menunjukkan bahwa konsentrasi ekstrak kulit nanas $0 \%$ sampai $40 \%$ berpengaruh tidak nyata $(\mathrm{P}<0.05)$ terhadap nilai keempukan daging. Hal ini dikarenakan daging bebek petelur afkir bertekstur alot atau keras. Sehingga enzim proteolitik dalam ekstrak kulit nanas $0 \% \%$ sampai dengan konsentrasi $40 \%$ belum mampu bekerja secara optimal dalam memutus ikatan peptida dalam daging, sehingga belum mengempukkan daging. Hal ini dikarenakan nilai daya ikat air semakin menurun. Nilai keempukan daging dipengaruhi oleh nilai daya ikat air daging, dimana semakin rendah nilai daya ikat air, maka semakin rendah keempukan daging. Selama perendaman terjadi proses glikolisis anaerob menyebabkan terbentuknya asam laktat. Semakin banyak asam laktat yang terakumulasi maka protein semakin banyak terdenaturasi sehingga tidak mampu mengikat air. Semakin sedikit air bebas yang diikat oleh protein didalam daging maka semakin rendah nilai keempukan daging. Hal ini sesuai dengan pendapat Koswara (2007) yang menyatakan bahwa jika enzim protease bekerja 
pada daging maka protein daging dapat diuraikan, sehingga daging menjadi empuk. Menurut Lawrie (1995), salah satu hal yang mempengaruhi tekstur daging adalah kandungan jaringan ikat serta ukuran berkas otot. Winarno (1997) menyatakan bahwa keaktifan ensim protease ditentukan oleh tingkat keasaman dari produk pangan.

\section{Kesimpulan}

\section{KESIMPULAN DAN SARAN}

Ditinjau dari aspek uji kualitas fisik dan kualitas organoleptik perendaman ekstrak kulit nanas pada daging bebek afkir tidak terjadi interaksi yang nyata $(\mathrm{P}<0,05)$ antara lama perendaman ekstrak kulit nanas dan konsentrasi yang berbeda terhadap pengempukan daging bebek petelur afkir, karena Fhitung < Ftabel $(\mathrm{P}<0,05)$, tetapi berpengaruh nyata $(\mathrm{P}<0,05)$ terhadap $\mathrm{pH}$, warna dan tekstur, karena Fhitung $>$ Ftabel $(\mathrm{P}<0,05)$. Pada konsentrasi $20 \%$ selama 60 menit dapat meningkatkan presentasi tingkat kesukaan terhadap warna dengan nilai rata-rata $(31,88)$ dan tekstur dengan nilai ratarata $(30,77)$. Tetapi belum mampu memperbaiki nilai aroma, susut masak dan pengempukan ekstrak kulit nanas mampu menurunkan nilai $\mathrm{pH}$ daging bebek afkir dengan nilai rata-rata $(5,76)$.

\section{Saran}

Perlu diadakan penelitian lebih lanjut tentang penambahan konsentrasi dan waktu yang berbeda untuk menghasilkan tekstur bebek afkir yang lebih baik.

\section{DAFTAR PUSTAKA}

Aeni, E. N. 2009. Kutu Putih (Hemiptera: Pseudococcidae) pada Tanaman Nanas (Ananas Comosus (Linn.) Merr.) di Desa Bumihayu Kecamatan Jalancagak, Kabupaten Subang. Skripsi. Fakultas Pertanian. Institut Pertanian Bogor. Bogor.

Aberle, E.D., J.C. Forrest, H.B. Hendrick, M.D. Judge dan R.A. Merkel. 2001. Principles of Meat Science. W.H. Freeman and Co., San Fransisco

Asryani, D. M. 2007. Eksperimen Pembuatan Kecap Manis dari Biji Turi dengan Bahan Ekstrak Buah Nanas.Skripsi. Fakultas Teknik. Universitas Negeri Semarang. Semarang.
Attayaya. 2008. Manfaat Tanaman Nenas. http://attayaya.blogspot.com. Diakses pada tanggal 23 Juni 2016.

Dhiah, P.U. 2011. Manfaat Bromelin dari Ekstrak Buah Nanas (Ananas Comosus L. Merr) dan dan Waktu Pemasakan Untuk Meningkatkan Kualitas Daging Itik Afkir.Sains Peternakan Vol. 9, No. 2. 8287

Ensminger, A. H., Ensminger M. E., Konlande J. E., and Robson J. R. K. 1994. The Concise Encyclopedia of Foods and Nutrition. Boca Raton: CRC Press

Fajararizz. 2010. Peluang Beternak Bebek. http :// www. Peternakandody .com/berita- 116 - peluang - beternakbebek.html.

Ferdiansyah, V. 2005. Pemanfaatan Kitosan Dari Cangkang Udang Sebagai Matriks Penyangga Pada Imobilisasi Enzim Protease. Skripsi. Jurusan Teknologi Hasil Pertanian. Fakultas Perikanan dan Ilmu Kelautan.Institut Pertanian Bogor. Bogor.

Hartono, Edi., Ning Iriyanti, dan R. Singgih Sugeng Santosa. 2013. Penggunaan Pakan Fungsional Terhadap Daya Ikat Air, Susut Masak, Dan Keempukan Daging Ayam Broiler. Jurnal Ilmiah Peternakan Vol. 1, No. 1, Hlm. 10-11

Kartika, B., P. Hastuti dan W. Supartomo. 1988. Pedoman Uji Inderawi Bahan Pangan : PAU Pangan dan Gizi. Gadjah Mada University Press: Yogyakarta.

Komariah, I. 2004. Kualitas fisik dan mikroba daging sapi yang ditambah jahe (Zingiber Officinale Roscoe) pada konsentrasi dan lama penyimpanan yang berbeda. Media Peternakan Hal. 46-54.

Koswara. 2007. Dadih atau Curd. http://ptp2007.wordpress.com/2008/06/03/ dadih/. Diakses [23 Juni 2016].

Lawrie, R. A. 2003. Meat Science. Penerjemah: Aminudin Parakasi. UI-Press. Jakarta.

Lingga, L. 2012. The Healing power of antioxidant : Mengenal Lebih Jauh Sumber Antioksidan Unggulan. Jakarta : Elex Media Komputinda

Muniarti. 2006. Manfaat Nanas. Wab-site: http://rocky-16-amelungi.wordpress.com. Diakses: Tanggal 27 April 2016 
Obuz, E., M.E. Dikeman., J.P. Grobbel., W. Stephens., T.M. Loughin. 2004. Beef Longissimus Lumborum, Biceps Femoris And Deep Pectoralis Warner-Bratzler Shear Force Is Affected Differently By Endpoint Temperature, Cooking Method And Usda Quality Grade. Meat Sci. 68:243-248.

Prasetio, Bambang. 2010. 16 Peluang Usaha Top Bidang Peternakan Panduan Sukses Menjadi Peternak Unggulan. Yogyakarta: Lily Publisher.

Prihatman, K. 2000. TentangBudidaya Pertanian: Kedelai. Deputi Menegristek Bidang Pendayagunaan dan Pemasyarakatan IlmuPengetahuan dan Teknologi.

Purnamasari, E. 2012. Sifat Fisik Daging Ayam Petelur Afkir Yang Direndam Dalam Ekstrak Kulit Nanas (Ananas Comosus L. Merr) dengan Konsentrasi Yang Berbeda. Jurnal Peternakan Vol. 9, No. 1, Hlm. 1-8

Prost E, Pelczynska E. And Kotula A.W. 1975. J. Anim Scin. $41 ; 534$

Rakhmadi, A., D. Novia, dan D. Rena. 2009. Karakteristik Bakso Itik Afkir Dengan Subtitusi Beberapa Jenis Tepung Dengan Jumlah Yang Berbeda. Skripsi Fakultas Peternakan, Universitas Andalas, Padang.

Rugayah, N. 2006. Studi Kandungan Timbal (Pb) Dan Cadmium (Cd) Pada Daging Sapi Dan Kambing. J. Ilmiah Santina 3(4).

Rugayah, N. 2008. Keempukan Daging Sapi Pada Lama Pelayuan dan Jenis Otot Yang Berbeda. J. Penelitian Mimbar Akademik XVIII: 28.

Saleh, 2004. Evaluasi Gizi Pada Pengolahan Bahan Pangan. Penerbit Institut Teknologi Bandung. Bandung.

Septiatin, E. 2009. Apotek Hidup dari Tanaman Buah. Bandung: CV. Yrama Widya Hal. 81-88

Shanks, B.C., D.M. Wolf., dan R.J. Maddock. 2002. Technical note: The effect of freezing on Warner Bratzler shear force values of beef longissimus steak across several postmortem aging periods. $\mathrm{J}$. Anim. Sci. 80:2122-2125.

Sitorus, A. 2001. Aplikasi Enzim Bromelin dari Larutan Ekstrak Nenas pada Proses Pengempukan Daging Kambing Betina
Tua. Skripsi Fakultas Peternakan Institut Pertanian Bogor. Bogor

Soekarto, 1985. Penilaian Organoleptik untuk Industri Pangan dan Hasil Pertanian. Pusat Pengembangan Teknologi Pangan. IPB, Bogor

Soeparno. 2005. Ilmu dan Teknologi Daging. Cetakan Ke-Empat. Gadjah Mada University Press, Yogyakarta

Soeparno. 2009. Ilmu dan Teknologi Daging. Gadjah Mada University Press. Yogyakarta.

Srigandono, B. 2000. Produksi Unggas Air. Gadjah mada University Press, Yogyakarta.

Steel, R. G. D dan Torrie, J. H. 1995. Prinsip dan Prosedur Statistik. Gramedia, Jakarta.

Suprapti, L. 2008. Produk-produk Olahan Ikan. Penerbit Kanisius. Yogyakarta.

Utami, K..P. 1996. "Perkembangan ltik Di Luar Negeri". Dalam Trubus. (Oktober,XXVIlI). No. 301. Jakarta : balaman 10 - 11 .

Winastia, B., 2011. Analisa Asam Amino pada Enzim Bromelin dalam Buah Nanas (Ananas Comusus) Menggunkan Spektrofotometer. Tugas Akhir. Program Studi Diploma III Teknik Kimia, Program Diploma, Fakultas Teknik Universitas Diponegoro, Semarang.

Yati, S. 2013. Pengaruh Perendaman Dalam Ekstrak Buah Mengkudu (Morinda Citrifolia) Terhadap Kualitas Sensori Daging Bebek Afkir. Jakarta

Zuhra C. 2006. Flavor (Citarasa). www.library.usu.ac.id. [23 Juni 2016]. 